Сукина Л. Б. Визуальные источники русского Средневековья в историческом исследовании : некоторые методологические наблюдения // Философия. Журнал Высшей школы экономики. - 2020. - Т. 4, № 4. - С. 113-132.

ЛюАМИлА СукинА*

\title{
ВИЗУАЛЬНЫЕ ИСТОЧНИКИ
}

РУССКОГО СРЕАНЕВЕКОВЬЯ

\section{В ИСТОРИЧЕСКОМ ИССЛЕАОВАНИИ**}

\author{
НЕКОТОРЫЕ МЕТОАОЛОГИЧЕСКИЕ НАБЛЮАЕНИЯ
}

Получено: 22.06.2020. Рецензировано: 20.09.2020. Принято: 20.10.2020.

Аннотация: В статье рассматривается проблема методологических трудностей работы историков с визуальными источниками русского Средневековья. Ее актуальность определена парадоксальной эпистемологической ситуацией, сложившейся в исторической науке в результате визуального поворота. Историки, занимающиеся исследованием русского Средневековья и постоянно испытывающие нехватку источников, могли бы значительно расширить находящуюся в их распоряжении источниковую базу, но они традиционно невысоко оценивают информационный потенциал древнерусского искусства. Профессиональная среда исследователей русского Средневековья довольно консервативна. Большинство историков по-прежнему ориентировано на письменные источники. С другой стороны, методология и методика исследования средневековых визуальных источников пока еще слабо разработаны. Опасения историков неверно «прочесть» заключенную в них информацию небезосновательны, так как верифицировать ее с помощью письменных источников, как предлагали крупные российские теоретики источниковедения М. Н. Тихомиров, С. О. Шмидт, И.А. Ковальченко, В. А. Плугин, удается далеко не всегда. Рассуждения автора данной статьи базируются на теоретическом положении, сформулированном и обоснованном в работах О.М. Медушевской, согласно которому исследуемая источниковедением эмпирическая реальность мира прошлого представляет собой структуру типов и видов исторических источников. Визуальные источники русского Средневековья рассматриваются как тип источников, созданных и функционировавших в дискурсе определенной культуры. В статье анализируются методологические идеи, связанные с проблемами «дешифровки» и интерпретации информации русских и европейских средневековых визуальных источников, содержащиеся в работах структуралистов (М. Ю. Лотмана, Б. А. Успенского), специалистов в области иконографии и иконологии (Э. Панофского, Э. Гомбриха), символической истории (М. Пастуро), методолога источниковедения А. С. Лаппо-Аанилевского. Видовые и исторические особенности этого типа источников создают серьезные сложности для историков, требуют освоения методологии работы с «нереалистическими» изображениями, но и открывают перспективы для содержательного обогащения исследований. Российская и зарубежная

* Сукина Людмила Борисовна, д. ист. н., Институт программных систем им. А.К. Айламазяна РАН (Переславль-Залесский), lbsukina@gmail.com, ORCID: 0000-0001-7692-2085.

** (C) Сукина, Л. Б. (C) Философия. Журнал Высшей школы экономики. 
наука накопила в этой сфере достаточный теоретический и практический опыт. Поэтому можно надеяться, что исследования визуальных источников русского Средневековья будут расширяться и займут достойное место в корпусе исторического знания.

Ключевые слова: методология источниковедения, типы и виды источников, информационный потенциал, визуальный источник, методы интерпретации, древнерусское искусство, история русского Средневековья.

DOI: $10.17323 / 2587-8719-2020-4-113-132$.

Визуальный поворот в исторической науке уже признан и в зарубежной, и в российской историографии свершившимся фактом. Важная роль визуальных источников в современных исторических исследованиях и репрезентации их результатов не подлежит сомнению. Источниковая ценность фотоизображений, документальных кинокадров, реалистической живописи или рисунков очевидна. Но историки, занимающиеся исследованием русского Средневековья, по-прежнему невысоко оценивают информационный потенциал древнерусского искусства. При этом каждый из них в собственной исследовательской практике так или иначе сталкивался с нехваткой исторических источников или неполнотой содержащейся в них информации, что и сегодня остается серьезным препятствием для создания верифицируемых с помощью научных методов реконструкций событий и явлений прошлого.

Отчасти скептическое отношение к визуальным источникам связано с тем, что большинство исследователей по-прежнему ориентированы в первую очередь на письменные источники, которые, согласно авторитетному мнению классика отечественной науки и признанного специалиста по истории средневековой Руси М. Н. Тихомирова,

...являются наиболее важными для историков: они- - ундамент исторического исследования. Там, где письменные источники отсутствуют, историк бродит в потемках, и на страницах исторических изданий появляются проблемы, слабо восполнимые изучением других видов источников (Тихомиров, 1962: 8).

Несомненно, М. Н. Тихомиров был знаком с осуществленными А. В. Арциховским (Арциховский, 1944) и Н.Н. Ворониным (Воронин, 1954) источниковедческими исследованиями древнерусской миниатюры и архитектуры. Но при этом с полным на то основанием он мог утверждать приоритет письменных источников в историческом исследовании, так как предложенные в публикациях названных авторов идеи, к сожалению, тогда не получили большого применения. Только десять лет спустя 
вышла известная работа О.И. Подобедовой о миниатюрах русских исторических рукописей (Подобедова, 1965). В последующие десятилетия источниковедческие исследования лицевого летописания были продолжены трудами С. О. Шмидта (Шмидт, 1984), А. А. Амосова (Амосов, 1990) и др. Одним из важных результатов деятельности ученых в этом направлении стала разработка методики описания и изучения комплекса лицевых летописей (Лицевой летописный свод, 2003). Необходимо подчеркнуть, что все упомянутые историки, апеллировавшие к информационной ценности визуальных источников русского Средневековья, все же рассматривали их в первую очередь как дополнительный и преимущественно иллюстративный материал к той информации, которую давали письменные источники.

На эту и ныне остающуюся актуальной специфику мышления историков обращают внимание современные исследователи, склонные к методологической рефлексии. Например, Л. Н. Мазур справедливо отмечает, что «визуальный поворот в исторической науке совершается медленнее, чем в социологии и культурологии», вероятно, потому что историки привыкли иметь дело с письменным источником, который «остается основой исторического познания и его символом», а «видимость» визуального источника для них - понятие отвлеченное (Мазур, 2019: 57).

Существует и еще одна сторона проблемы, имеющая специфически источниковедческий характер. Хотя в последнее время все чаще появляются работы, посвященные теории и практике классификации и анализа изобразительных источников (Терентьева, 2010: 470-484), методология и методика исследования визуальных источников пока еще слабо разработаны. Особенно это касается средневековых источников, содержание и смысл которых не столь очевидны, как у реалистических изображений, созданных в Новое и Новейшее время. И потому опасения историков неверно «прочесть» заключенную в них информацию небезосновательны.

При этом интерес к визуальным источникам - в первую очередь у исследователей истории русской средневековой культуры - поддерживается уже на протяжении многих десятилетий и продолжает постепенно развиваться. Об этом, например, свидетельствуют сразу несколько публикаций в недавнем сборнике «Роль изобразительных источников в информационном обеспечении исторической науки». Среди них стоит выделить статью В. Д. Черного, попытавшегося описать русское 
средневековое искусство как информационную систему, хранящую разнообразные сведения о целой эпохе (Черный, 2019). Но теоретический уровень этих и многих других работ (содержащих, надо отметить, весьма полезные для исследовательской практики наблюдения) можно в целом охарактеризовать словами В. Вжосека (Вжосек, Ерусалимский, 2012: 235):

Источниковедческая рефлексия обычно декретирует, чем является источник, предопределяя, в силу очевидности, его познавательный смысл, или же замалчивает эту тему, предоставляет какую-нибудь дефиницию исторического источника и переходит к рассуждениям о том, как обращаться с его конкретными видами.

Впрочем, следует заметить, авторы большинства публикаций не делают и этого, а сразу же переходят к дескрипции определенной группы художественных произведений, содержащей интересующую их информацию о прошлом.

В связи с вышесказанным обращение к анализу методологических аспектов исследования визуальных источников русского Средневековья, раскрытия их информационного потенциала представляется важным и своевременным. В своих рассуждениях мы будем исходить из теоретического положения, сформулированного и обоснованного в работах О. М. Медушевской, согласно которому исследуемая источниковедением эмпирическая реальность мира прошлого представляет собой структуру типов и видов исторических источников (Медушевская, 2008а, Медушевская, 2008b). Это положение сохраняет актуальность и в неоклассической концепции источниковедения, нацеленной на получение строго научного знания (Румянцева, 2017: 49).

Визуальные («изобразительные» в терминологии того времени) источники обрели свое законное место как один из основных типов источников в классификациях, представленных в 1980-е гг. в трудах крупнейших отечественных теоретиков источниковедения. С. О. Шмидт, стремясь преодолеть чрезмерную узость уже неоднократно обоснованного к тому времени в литературе подразделения всех источников на письменные и бесписьменные, выделил изобразительные источники в особый «класс» на основе присущих им формальных свойств, обеспечивающих им «известную автономность» в системе источников «исторического происхождения» (Шмидт, 1985: 20). В примечании к соответствующей позиции в предложенной им классификации ученый пояснял, что выделение особого типа изобразительных источников (несмотря на то что все они 
являются еще и вещественными) обусловлено тем, что «они - в отличие от большинства вещественных источников - несут, как правило, дополнительную культурно-историческую информацию, „изображая“ иное явление» (Шмидт, 1985: 21). Именно «изобразительная» информация этих источников воспринимается исследователем как основная, а их «вещественность» превращается в дополнительное свойство.

В классификации С. О. Шмидта изобразительные источники подразделялись на три подтипа или подкласса: (а) художественно-изобразительные (произведения изобразительного искусства, искусства кино и фотографии); (б) изобразительно-графические (содержащие информацию, выражаемую при помощи наглядных графических образов, не составляющих алфавита); (в) изобразительно-натуральные (прежде всего документальные фотографии и кинокадры) (там же).

Предложенная типология была эксплицирована ее автором как «элементарная» и сугубо «прикладная», опирающаяся и рассчитанная на интеллектуальные традиции учебной, музееведческой и краеведческой деятельности и «источниковедческой практики». При этом, ссылаясь на вызвавшую в то время широкий резонанс работу А. С. Уйбо (Уйбо, 1983), С. О. Шмидт отмечал, что было бы интересно рассмотреть проблемы классификации исторических источников в плане концепции «социальной памяти» (Шмидт, 1985: 23-24).

И. Д. Ковальченко в своей известной работе «Методы исторического исследования» ${ }^{1}$, казалось бы, как раз и начал с того момента, на котором остановился С.О. Шмидт. В предложенной им дефиниции изобразительные источники отличаются «особой формой выражения социальной информации» (Ковальченко, 2003: 133). Но далее, утверждая, что наиболее общим из трех аспектов информации (прагматического, семантического и синтаксического), которые можно положить в основание классификации источников, наиболее общим является синтаксический, И. Д. Ковальченко опять поделил всю совокупность источников на категории и типы «по методам и формам отражения действительности» (там же: 135). И классификация изобразительных источников у него совпала с предложенной С. О. Шмидтом: изобразительно-графические, изобразительно-художественные, изобразительно-натуральные.

В труде И. Д. Ковальченко впервые довольно много внимания было уделено специфике источниковедческого анализа изобразительных источников, который, по справедливому замечанию автора, оказывается

\footnotetext{
${ }^{1}$ Первое издание вышло в 1987 г., второе, дополненное, в 2003 г.
} 
значительно более сложным, чем анализ обычных письменных источников (Ковальченко, 2003: 134). Причина этой сложности заключается в том, что зафиксированная в изобразительных источниках информация об исторической действительности закодирована в визуальных образах и потому остается скрытой для исследователя. При дешифровке изобразительного источника историк должен осуществить процедуру «снятия» присущей эпохе создания этого источника системы изобразительных принципов и методов, скрывающих содержание. Извлеченная из изобразительного источника информация должна быть подкреплена дополнительной информацией из других (преимущественно письменных) источников и получить «естественно-языковое» выражение (там же: 133-134). По мнению И. Д. Ковальченко, эта задача «особенно важна применительно ко всякого рода нереалистическим отражениям действительности» (курсив наш-автор) (там же: 133).

Визуальные источники русского Средневековья за малым исключением как раз и относятся к тем, в которых отсутствует «реализм» содержания и формы, свойственный искусству Нового времени. Хотя это и довольно очевидно, но длительное время обращавшиеся к ним историки продолжали искать в них элементы «реальной действительности» и вполне закономерно каждой раз испытывали разочарование в информационной полезности фресок, икон, книжных миниатюр, памятников архитектуры для исторического исследования. Портреты, пейзажи, батальные и бытовые сцены в средневековых изображениях не имеют почти ничего общего с исторической реальностью. Они предельно условны, ориентированы на иконографический образец, художественную традицию, изобразительную норму, формировавшиеся и существовавшие в искусстве византийского мира на протяжении целого тысячелетия.

Информационная специфика русского средневекового искусства стала предметом исследования у представителей московско-тартусской семиотической школы в 1970-е гг. Многие из опубликованных тогда работ в исправленном и дополненном виде были переизданы в 1990-2000-е гг. Исследуя семиотику древнерусской иконы, Б.А. Успенский отмечал (Успенский, 1995: 221):

K произведению старого искусства правомерно подходить как к предмету дешифровки, пытаясь выявить особый язык художественных приемов, т. е. специальную систему передачи того или иного содержания на плоскости 
картины. Трудности подобной дешифровки определяются тем обстоятельством, что нам обычно неизвестны с достаточной полнотой не только приемы выражения, но и само содержание древнего изображения.

К сожалению, приходится констатировать, что иконографические программы сложных средневековых композиций, если и были в свое время зафиксированы в виде письменного текста, то не дошли до нас. Поэтому и та дополнительная информация, с помощью которой можно было бы верифицировать результаты дешифровки иконописных сюжетов и образов, также не может быть сравнительно легко добыта историком.

Подавляющее большинство средневековых визуальных источников относится к подтипу художественно-изобразительных (в классификации Шмидта - Ковальченко). Они созданы в канонической системе искусства, ориентированной на ритуальность и тождественность формы и содержания, в которой акт художественного творчества состоял в выполнении фиксированных эстетических норм и правил. Постоянное повторение на протяжении длительного времени (веков и десятилетий) одних и тех же композиционных схем, изобразительных и декоративных элементов, казалось бы, лишает содержащуюся в средневековых изобразительных источниках информацию исторического динамизма и тем самым обесценивает ее для исследователя. Кроме всего прочего, эти особенности средневековых изображений затрудняют применение к ним привычных методических приемов анализа, которые положительно зарекомендовали себя в работе с художественными «текстами» (в широком смысле этого понятия) Нового времени.

В статье, впервые опубликованной в 1973 г., Ю. М. Лотман вскрыл парадоксальность исследовательского подхода, уподобляющего «ограниченный словарь» и «нормализованную грамматику» средневековья естественному языку и изучающего канонические типы искусства по аналогии с ним. В действительности же художественные тексты, создававшиеся в рамках «эстетики тождества» строятся по иному принципу: «...область сообщения у них предельно канонизируется, а „язык“ системы сохраняет неавтоматизированность», и исследователь имеет дело с системой с фиксированным содержанием и «неавтоматизированным» механизмом, «постоянно ощущаемым в процессе общения» (Лотман, 2002: 315$)$.

В своих наблюдениях Ю. М. Лотман основывался на опыте исследования фольклорных текстов, но они верны и для оценки информационной 
специфики любых других видов и форм канонического искусства. Особенно значим итоговый вывод статьи: для понимания текстов, в которых соблюдаются ритуальные и канонические нормы и правила, недостаточно описать их внутреннюю синтагматику, так как в этом случае мы получим «чрезвычайно существенный, но не единственный пласт структурной организации» (Лотман, 2002: 319). Без ответа останутся очень важные вопросы: что означал данный текст для создавших его людей и как он функционировал в социокультурной среде своего времени. Соответствующая информация в самих текстах отсутствует, их прагматику и социальную семантику можно реконструировать, только привлекая другие источники.

При попытке выяснить, откуда берется и как агрегируется информация, составляющая содержание художественного текста, созданного внутри канонической системы искусства, мы сталкиваемся с парадоксальной ситуацией, когда становится очевидно, что ориентация на канон может принадлежать как самому тексту, так и нашему его восприятию. Между структурой текста и ее осмыслением в контексте породившей этот текст культуры могут быть существенные различия. Ю. М. Лотман подчеркивал (там же: 320$)$ :

Не только отдельные тексты, но и целые культуры могут осмыслять себя как ориентированные на канон. Но при этом строгость организации на уровне самоосмысления может компенсироваться далеко идущей свободой на уровне построения отдельных текстов. Разрыв между идеальным самоосмыслением культуры и ее текстовой реальностью в этом случае становится дополнительным источником информации.

Предложенное Ю. М. Лотманом определение канонического искусства как информационного парадокса очень важно для интерпретации формы и содержания визуальных источников русского Средневековья с использованием категорий традиции и новаторства и оценкой их взаимоотношений.

Однако по сравнению с текстом письменного источника или фольклорным текстом структура визуального источника, выстроенная как система образов, имеет и собственную, особую специфику, отдельно осмысливаемую в источниковедческой теории и практике. Для исследования визуальных источников русского Средневековья в отечественной историографии особое значение имела работа В. А. Плугина, посвященная реконструкции мировоззрения иконописца XIV - первой четверти 
XV в. Андрея Рублева на основе источниковедческого анализа произведений этого художника (Плугин, 1974). В теоретической преамбуле к основной части исследования было отчетливо обозначено, что автор исследования осознавал сложность стоявшей перед ним задачи. Это, в частности, явственно читается в предложенной им дефиниции древнерусской иконы как исторического источника (там же: $3-4$ ):

Специфика иконы как источника заключается, прежде всего, в том, что как всякое произведение искусства, она отражает образ мышления создавшего ее мастера (и, в конечном счете, общественную идеологию) гораздо более опосредованно, чем летопись или акт. А как произведение изобразительного искусства ставит дополнительную задачу расшифровки ее образного языка. Наконец, как типичное порождение культуры средневековья, обслуживающее, прежде всего, религиозные потребности общества, икона ограничена определенным кругом отвлеченных церковных сюжетов, а внутри каждого из них традиционной схемой его изображения (иконография), за которой не так легко разглядеть реальное историческое лицо художника и его эпохи.

Несмотря на то что на титуле исследования в качестве основного исторического источника были выведены иконы Андрея Рублева, расшифровка их смыслов осуществлялась на основе анализа широкого круга письменных источников: летописей, актов, памятников агиографии, богословских и полемических сочинений. При этом формальностилистический и иконографический методы, традиционные для искусствоведческих исследований иконописи, были задействованы минимально. В результате В. А. Плугину удалось реконструировать общественную идеологию эпохи Куликовской битвы, в атмосфере которой разворачивалось творчество Андрея Рублева. Что же касается характеристики мировоззрения прославленного мастера иконописи, то здесь все оказалось не так однозначно. Отталкиваясь в своих построениях не от визуальных, а от письменных источников и отказавшись от решения проблемы «подлинности» первых, исследователь оказался в ловушке (о которой тогда, к счастью для себя, не мог даже подозревать). В наши дни принадлежность целого ряда произведений Андрею Рублеву, с именем которого их в 1960-1970-х гг. связывали искусствоведы, подвергается сомнению. Поэтому единственно релевантным представляется вывод о том, что В.А. Плугин в своей работе очертил круг мировоззренческих идей, близких всей элитарной группе иконописцев конца XIV - начала XV в., работавших в крупнейших городах Московского княжества. Иконы, приписываемые Андрею Рублеву (преимущественно 
на основании косвенных и не очень надежных данных письменных источников), являются скорее иллюстрацией этих идей, чем основным источником информации об их содержании и распространении. Фактически мы имеем дело с той же методологией примата информации письменного источника. А информация, полученная при анализе визуального источника, встраивается в уже готовую матрицу.

Не только российские, но и западные медиевисты зачастую используют визуальные источники преимущественно для иллюстрирования и подкрепления выводов, полученных в результате анализа письменных источников. Как правило, они не уделяют внимания формальнохудожественным характеристикам и особенностям произведений искусства: «У того, кто помещает себя в отчетливо историческую перспективу, решение не касаться собственно стилистических материй не должно вызывать возражений» (Гинзбург, Велижев, 2019: 26). О междисциплинарности визуальных исследований часто говорят, но в реальности она редко реализуется, хотя историки и искусствоведы (историки искусства) могли бы работать вместе, как предлагает К. Гинзбург (там же), чтобы достичь более глубокого понимания художественных свидетельств прошлого. По крайней мере, историкам-медиевистам было бы полезно присмотреться к работе своих коллег, изучающих изображения. Имплицитно выраженный отказ историков от искусствоведческих методов исследования визуальных источников затрудняет осуществление важных источниковедческих процедур, каковыми являются датировка исследуемых памятников (абсолютное большинство памятников русского средневекового искусства не имеют даты создания, зафиксированной в письменном виде на них самих или в каких-либо письменных источниках) и определение места их создания. Должна осуществляться не только деятельность искусствоведов, но и атрибуция изучаемого произведения искусства художественной школе или конкретному мастеру (если этого не было сделано ранее).

Несмотря на положительный сдвиг в сторону интереса к визуальным источникам в исторических исследованиях медиевистов, изучающих русское Средневековье, наблюдаемый в последнее десятилетие (Юрганов, 2013; Антонов, 2019), историки по-прежнему практически не используют в своей работе с изображениями методологический потенциал иконографических / иконологических штудий, которые успешно развивались в западном искусствознании хх в. (Варбург, Козина, 2008; Гомбрих, Доброхотова-Майкова, 2017; Панофский, Симонов, 1999). Поэтому мы уделим этому вопросу особое внимание. 
Теоретические построения Э. Панофского, выделившего три уровня исследования произведения изобразительного искусства (доиконографическое описание, иконографический анализ и иконологическая интерпретация), чрезвычайно важны для историков, имеющих дело с «нереалистическими» (символическими и аллегорическими) изображениями в русской иконописи, нуждающимися в сложной дешифровке. На уровне доиконографического описания, не преступающего границ мира мотивов, распознавание элементов изображения опирается на практический опыт исследователя, дополняемый сведениями из специальных трудов и справочников. Доиконографическое описание в источниковедческом исследовании может быть частью операции, которую принято называть «внешней критикой» источника. Иконографический анализ затрагивает уже не столько мотивы, сколько образы, сюжеты и аллегории и предполагает знакомство со специфическими темами и понятиями, для освоения которых необходимо проделать серьезную историографическую работу. Иконологическая интерпретация требует тонкой профессиональной настройки исследователя, соединенной с внутренней способностью, родственной интуиции, позволяющей проникнуть в подлинный смысл произведения искусства (Панофский, Симонов, 1999: 44-57).

Как и в источниковедении, имеющем дело с письменными источниками, в исследовании произведения искусства одной из главных задач и проблем остается синтез результатов, осуществляемый на каждом из уровней работы. По мнению Э. Панофского,

«на каком бы уровне мы ни действовали, предлагаемые нами идентификации и интерпретации будут зависеть от нашей субъективной подготовленности. И именно поэтому их следует подкреплять и корректировать, познавая исторические процессы, которые в сумме можно назвать традицией» (там же: 56).

Занимаясь дешифровкой «нереалистических» изображений Средневековья, историк, как и искусствовед, должен осознавать возможность оказаться в плену собственных интерпретаций и утратить связь с объектом исследования, имманентной ему системой смыслов и значений, что может привести к «переизобретению» объекта в познающем разуме исследователя. Недаром Э. Панофский полушутя высказывал опасение, что, совершая шаг на новый уровень по сравнению с иконографией, иконология при отсутствии интеллектуальной самодисциплины ученого «поведет себя не как этнология по отношению к этнографии, а скорее, как астрология по отношению к астрографии» (там же: 49). Э. Гомбрих, 
рассуждая о целях и границах иконологии (под которой он понимал в первую очередь реконструкцию программы изображения) в интерпретации символических образов искусства, отмечал, что интерпретатор может слишком удалиться от намерения создателя художественного изображения и утратить понимание того значения, которое было для художника и его современников основным (Гомбрих, ДоброхотоваМайкова, 2017: 28).

Иногда плодотворные идеи понимания отдельных особенностей средневековых изображений могут поступать от представителей других областей знания. Так, известный отечественный математик Б. Р. Раушенбах, увлекшись в 1970-1980-х гг. вопросами формально-математического обоснования приемов перспективных построений в живописи, заострил в своих работах давно известную историкам древнерусского искусства проблему «геометрических построений» обратной перспективы в иконописи. Изучив ее, он пришел к выводу том, что нужно проводить исследовательскую процедуру, направленную на выявление использованных создателем конкретного произведения методов обратной перспективы и необходимости их использования. Без этого невозможно достичь понимания, как древнерусский художник и зритель видели и представляли реальный и иллюзорный миры иконного изображения (Раушенбах, 1975).

Основатель современной «символической истории» М. Пастуро, говоря о методологических трудностях интерпретации символики цвета, призывает исследователей, работающих со средневековыми визуальными источниками, не забывать об их самоценности, автономности, видовых и исторических особенностях (Пастуро, Решетникова, 2019: 121-122):

..оставленные средневековой культурой источники, письменные и изобразительные, никогда не бывают ни однозначными, ни нейтральными. Каждый источник имеет свою специфику и по-своему интерпретирует действительность. [...] Тексты и изображения вообще принадлежат к разным дискурсам и должны изучаться и анализироваться различными методами. Эту - совершенно очевидную - мысль часто забывают, особенно специалисты по иконографии и историки искусства, которые вместо того чтобы расшифровывать смысл самих изображений, наслаивают на них все, что почерпнули из других источников - в частности, из текстов. Медиевистам следовало бы иногда брать пример с исследователей доисторического периода, которые работают с изображениями (наскальными рисунками), не располагая при этом ни единым текстом: они вынуждены выдвигать гипотезы, искать зацепки и разгадывать смысл, анализируя непосредственно сами изображения, а не 
проецируя на них информацию, добытую из текстов. Историкам и историкам искусства стоило бы взять на вооружение их метод-по крайней мере, на первом этапе анализа.

В этом суждении несложно заметить перекличку с идеями Э. Гомбриха, высказанными в работе 1970-х гг., посвященной неоплатоническому символизму картин Боттичелли. Ученый установил, что сюжеты произведений этого прославленного мастера эпохи Возрождения долгое время интерпретировали неверно, так как исследователи «вчитывали» в них собственные знания об античной мифологии и тексты итальянских гуманистов, которые не имели к замыслам художника никакого отношения. Э. Гомбрих выдвинул осторожную гипотезу, что мифологические картины Боттичелли никогда не были прямой иллюстрацией литературных текстов, а основывались на не дошедшей до нас программе, составленной специально для них духовным наставником живописца Марсилио Фичино. Поэтому, чтобы уловить смысл символических композиций Боттичелли, исследователь должен в своих интерпретациях отталкиваться непосредственно от самого изображения и избегать соблазна напрямую сопоставить ему подходящие по сюжету фрагменты литературных произведений различных авторов (Гомбрих, Доброхотова-Майкова, 2017: 72-73).

Исследованиям визуальных источников русского Средневековья может принести немало пользы и актуализированная усилиями целого ряда ученых в течение трех последних десятилетий «Методология истории» А. С. Лаппо-Данилевского ${ }^{2}$, развивавшего в начале хх в. идеи немецкой неокантианской философии и психологии. Она содержала оригинальное учение об исторических источниках как о продуктах культуры, которое основывалось на системообразующем принципе «признания чужой одушевленности» (Румянцева, 1999: 141). Методом источниковедческого исследования у А. С. Лаппо-Данилевского выступало интерпретационное понимание источника как единого целого, его места в культурном контексте эпохи, а не верификация отдельных содержащихся в нем сведений, каковая нередко оказывается невозможной из-за отсутствия других «достоверных» источников того же времени. Исторический источник в методологической конструкции ученого представал в интегрирующей роли объекта всего гуманитарного знания

${ }^{2}$ Отметим, что исследовательские интересы А. С. Лаппо-Данилевкого как историка первоначально были сосредоточены на археологии и связаны с анализом вещей, а позже переместились на русскую культуру XVII-XVIII вв. 
как знания о человеке и различных проявлениях его психической деятельности. К таковым проявлениям не в последнюю очередь относится и способность к созданию изображений.

А. С. Лаппо-Данилевский дал собственную оригинальную трактовку одного из ключевых понятий позитивистской историографии - «факта» («фактума»). В его концепции «факт» приравнивался к источнику или к тому, что современная археология и антропология определяют термином «артефакт»: «Фактум - это то, что сделано. Но для историка этого мало. Для него - фактум - то, что кем-нибудь сделано. Скребок из камня есть факт. Слово А к C- есть факт» (Лаппо-Данилевский, 1913: 322). Таким образом, источник (письменный, вещественный, изобразительный) и есть та историческая реальность, которая доступна эмпирическому исследованию.

Большое значение для интерпретационного анализа визуальных источников могут иметь и заложенные А. С. Лаппо-Данилевским методологические основы компаративного источниковедения. Его основным объектом выступают не уникальные феномены культуры, а продукты типизирующего влияния социальной среды на человеческую психику виды исторических источников, внутри которых источники обретают общие надындивидуальные черты. Сравнение видов источников и их систем позволяет выделить общее и различное в обществах и культурах, принадлежащих к одному или разным хронологическим периодам. Такой подход позволяет уйти от иерархической классификации источников и от представлений об исключительной, главенствующей роли письменных источников в реконструкциях исторического мира Средневековья с его «молчаливым (бесписьменным) большинством».

Итак, проведенный нами историографический анализ обозначил две исследовательские традиции изучения визуальных источников. Одна из них опирается на анализ визуальных источников в комплексе с письменными. Ее методология и методика были разработаны в отечественной гуманитаристике второй половины хх в. (С. О. Шмидтом, И. Д. Ковальченко, В. А. Плугиным, М. Ю. Лотманом и др.). Она успешно реализуется сегодня в исследованиях визуальных источников Нового времени, например, русского портрета XVIII и XIX в., живописи исторического и бытового жанра, но не является столь эффективной в изучении средневековых «нереалистических» изображений, в том числе и из-за отсутствия связанных с ними письменных текстов. Поэтому историк русского Средневековья должен обратить внимание и на вторую традицию, которая сложилась и существует преимущественно в западном 
искусствоведении и визуальных исследованиях (Э. Гомбрих, Э. Панофский, М. Пастуро и др.) и практикует анализ визуальных источников без их связи с письменными.

Эпистемологический контекст исторического знания после визуального поворота, свершившегося в гуманитаристике, позволяет значительно расширить источниковую базу за счет визуальных источников. Это открывает путь для содержательного обогащения исследований, в том числе и в такой консервативной области, как история русского Средневековья, традиционно сориентированной на письменные источники. Но чтобы отказаться от привычного взгляда на изображение как всего лишь на иллюстрацию построений исследователя, основанных на информации, добытой из письменных источников, историк должен научиться дешифровке визуального источника как особого вида текста, возникшего и функционировавшего в ином виде дискурса. Но ему не придется начинать с нуля. Он может опираться на методологию источниковедения, предложенную А. С. Лаппо-Данилевским. Большой путь в поиске подходов к интерпретации средневековых изображений проделан семиотикой, иконографией и иконологией ХХ в. Методологические трудности работы с визуальными источниками Средневековья постоянно находятся в центре внимания современной символической истории. Поэтому можно надеяться, что исследования визуальных источников русского Средневековья будут расширяться и займут достойное место в корпусе исторического знания.

\section{ЛИТЕРАTУРA}

Амосов А. А. Лицевой летописный свод Ивана Грозного : Комплексное кодикологическое исследование. - М. : УРСС, 1990.

Антонов Д. И. Цари и самозванцы. Борьба идей в России Смутного времени. - М. : РГГУ, 2019.

Арииховский $A$. В. Древнерусские миниатюры как исторический источник. М. : МГУ, 1944 .

Вжосек B. Культура и историческая истина / пер. с пол. К. Ю. Ерусалимского. - М. : Кругъ, 2012.

Воронин Н. Н. Архитектурный памятник как исторический источник (заметки к постановке вопроса) // Советская археология. -1954 . - № $19 .-$ С. $4^{1-76}$. Гинзбург К. Загадка Пьеро : Пьеро делла Франческа / пер. с итал. М. Б. Велижева. - М. : Новое литературное обозрение, 2019.

Гомбрих Э. Символические образы. Очерки по искусству Возрождения / пер. с англ. Е. М. Доброхотовой-Майковой. - СПб. : Алетейя, 2017. 
Ковальченко И. Д. Методы исторического исследования. - М. : Наука, 2003. Лаппо-Данилевский А. С. Методология истории. - СПб., 1913.

Лицевой летописный свод XVI века : Методика описания и изучения разрозненного летописного комплекса / под ред. С. О. Шмидт, Е. А. Белоконь, В. В. Морозова. - М. : РГГУ, 2003.

Лотман Ю. М. Каноническое искусство как информационный парадокс // Статьи по семиотике искусства / под ред. Р. Г. Григорьевой. - СПб. : Гуманитарное агентство «Академический проект», 2002. - С. $314^{-} 3^{21}$.

Мазур Л. Н. Визуальный поворот в исторической науке : от текста к образу // Роль изобразительных источников в информационном обеспечении исторической науки : сборник статей / под ред. А. Г. Голикова, Е. А. Воронцовой. М. : Нестор-История, 2019. - С. $5^{2-72 .}$

Медушевская О. М. Теория и методология когнитивной истории. - М. : РГГУ, 2008 a.

Медушевская О.М. Эмпирическая реальность исторического мира // Вспомогательные исторические дисциплины - источниковедение - методология истории в системе гуманитарного знания : Материалы хх научной конференции. - М. : РГГУ, 2008b. - С. 24-34.

Панофский Э. Смысл и толкование изобразительного искусства / пер. с англ. В. В. Симонова. - СПб. : Академический проект, 1999.

Пастуро М. Символическая история европейского средневековья / пер. с фр. Е. С. Решетниковой. - СПб. : Александрия, 2019.

Плугин В. А. Мировоззрение Андрея Рублева (Некоторые проблемы) : Древнерусская живопись как исторический источник. - М. : МГУ, 1974.

Подобедова О.И. Миниатюры русских исторических рукописей (К истории русского лицевого летописания). - М. : Наука, 1965 .

Раушенбах Б. Р. Пространственные построения в древнерусской живописи. M. : Наука, 1975 .

Румянцева М.Ф. Методология истории А. С. Лаппо-Данилевского и современные проблемы гуманитарного знания // Вопросы истории. - 1999. № 8. - С. $138-146$.

Румянцева М. Ф. Источниковедение в структуре исторического знания : неоклассичекая модель науки // Ученые записки Петрозаводского государственного университета. - 2017. - Т. 166, № 5. - С. $44^{-} 5^{1}$.

Терентьева Л. А. Изобразительные источники : видовое разнообразие // Мультикультурная и многонациональная Россия : Материалы ІІ международной междисциплинарной конференции. Часть 1 / под ред. Н. В. Болдовской, Л. А. Терентьевой. - М. : РУДН, 2010. - С. 470-484.

Тихомиров М.Н. Источниковедение истории СССР. Вып. 1 (С древнейших времен до конца XVIII века). - М. : Издательство социально-экономической литературы, 1962. 
Уйбо А. С. Информационный подход к типологии исторических источников // Философские проблемы исторической науки : Труды по философии / под ред. Э. Лооне. - Тарту : Тартуский государственный университет, 1983 . - С. $3^{1-}$ 67.

Успенский Б. А. Семиотика иконы // Семиотика искусства. - М. : Школа «Языки русской культуры», 1995. - С. 221-294.

Черный В. Д. Русское средневековое искусство как информационная система : проблемы изучения // Роль изобразительных источников в информационном обеспечении исторической науки : сборник статей / под ред. А. Г. Голикова, Е. А. Воронцовой. - М. : Нестор-История, 2019. - С. 592-609.

Шмидт С. О. Российское государство в середине XVI столетия. Царский архив и лицевые летописи времени Ивана Грозного. - М. : Наука, 1984.

Шмидт С. О. О классификации исторических источников // Вспомогательные исторические дисциплины. - 1985. - Т. 16. - С. $3^{-24}$.

Юрганов А. Л. Художественный язык древней Руси как проблема (на примере Лицевого свода Ивана Грозного) // Россия XXI. - 2013. - № 3. - С. 110-131.

Sukina, L. B. 2020. "Vizual'nyye istochniki russkogo Srednevekov'ya v istoricheskom issledovanii [Visual Sources of Old Russia in Historical Research]: nekotoryye metodologicheskiye nablyudeniya [Some Methodological Observations]" [in Russian]. Filosofiya. Zhurnal Vysshey shkoly ekonomiki [Philosophy. Journal of the Higher School of Economics] 4 (4), 113-132.

\section{LYUDMILA SUKINA}

Doctor of Letters in History; Associate Professor; The Program Systems Institute of RAS (Pereslavl-Zalessky, RUSSia); ORCID: 0000-0001-7692-2085

\section{Visual Sources of Old Russia in Historical Research Some Methodological Observations}

Submitted: June 22, 2020. Reviewed: Sept. 20, 2020. Accepted: Jan. 20, 2020.

Abstract: The article considers the problem of the methodological difficulties of the work of historians with visual sources of Old Russia. Its relevance is determined by the paradoxical epistemological situation that has developed in historical science as a result of a visual turn. Historians who are researching Old Russia and constantly experiencing a shortage of sources could significantly expand the source base at their disposal, but they traditionally do not appreciate the information potential of ancient Russian art. The article analyzes methodological ideas related to the problems of "decryption" and interpretation of information from Russian and European medieval visual sources contained in the works of structuralism (Lotman, Uspensky), specialists in the field of iconography and iconology (Panofsky, Gombrich), symbolic history (M. Pasturo), source study methodologist Lappo-Danilevsky. The species and historical features of this type of sources create serious difficulties for historians, require the development of a methodology for working with "unrealistic" images, but also open up prospects for a meaningful enrichment of 
research. Russian and foreign science has accumulated sufficient theoretical and practical experience in this area. Therefore it is hoped that research on the visual sources of Old Russia will expand and take its rightful place in the corpus of historical knowledge.

Keywords: Source Study Methodology, Types and Classes of Sources, Informational Potential, Visual Source, Interpretation Methods, Ancient Russian Art, History of Old Russia.

DOI: $10.17323 / 2587-8719-2020-4-113^{-132}$.

\section{REFERENCES}

Amosov, A. A. 1990. Litsevoy letopisnyy svod Ivana Groznogo [Illustrated Chronicle of Ivan the Terrible]: Kompleksnoye kodikologicheskoye issledovaniye [Comprehensive Codicological Research] [in Russian]. Moskva [Moscow]: URSS.

Antonov, D. I. 2019. Tsari $i$ samozvantsy. Bor'ba idey v Rossii Smutnogo vremeni [Tsars and Impostors. The Struggle of Ideas in Russian in the Time of Troubles] [in Russian]. Moskva [Moscow]: RGGU.

Artsikhovskiy, A.V. 1944. Drevnerusskiye miniatyury kak istoricheskiy istochnik [Old Russian Miniatures as a Historical Source] [in Russian]. Moskva [Moscow]: MGU.

Chernyy, V. D. 2019. "Russkoye srednevekovoye iskusstvo kak informatsionnaya sistema [Russian Medieval Art as an Information System]: problemy izucheniya [Problems of Study]" [in Russian]. In Golikov and Vorontsova 2019, 592-6og.

Ginzburg, K. 2019. Zagadka P'yero [Indagini su Piero]: P'yero della Francheska [il Battesimo, il ciclo di Arezzo, la Flagellazione di Urbino] [in Russian]. Trans. from the Italian by M. B. Velizhev. Moskva [Moscow]: Novoye literaturnoye obozreniye.

Gombrich, E. 2017. Simvolicheskiye obrazy. Ocherki po iskusstvu Vozrozhdeniya [Symbolic Images] [in Russian]. Trans. from the English by Ye. M. Dobrokhotova-Maykova. Sankt-Peterburg [Saint Petersburg]: Aleteyya.

Koval'chenko, I. D. 2003. Metody istoricheskogo issledovaniya [Historical Research Methods] [in Russian]. Moskva [Moscow]: Nauka.

Lappo-Danilevskiy, A. S. 1913. Metodologiya istorii [Methodology of History] [in Russian]. Sankt-Peterburg [Saint Petersburg].

Lotman, Yu. M. 2002. "Kanonicheskoye iskusstvo kak informatsionnyy paradoks [Canon Art as an Information Paradox]" [in Russian]. In Stat'i po semiotike iskusstva [Papers on the Semiotics of Art], ed. by R. G. Grigor'yeva, 314-321. Sankt-Peterburg [Saint Petersburg]: Gumanitarnoye agent-stvo "Akademicheskiy proyekt".

Mazur, L. N. 2019. "Vizual'nyy povorot v istoricheskoy nauke [A Visual Turn in Historical Science]: ot teksta k obrazu [From Text to Image]" [in Russian]. In Golikov and Vorontsova 2019, 52-72.

Medushevskaya, O. M. 2008a. "Empiricheskaya real'nost' istoricheskogo mira [The Empirical Reality of the Historical World]" [in Russian]. In Vspomogatel'nyye istoricheskiye distsipliny - istochnikovedeniye - metodologiya istorii $v$ sisteme gumanitarnogo znaniya [Auxiliary Historical Disciplines - Source Study - the Methodology of History in the System of Humanitarian Knowledge] : Materialy XX nauchnoy konferentsii [Materials of the 2oth Scientific Conference], 24-34. Moskva [Moscow]: RGGU.

. 2008b. Teoriya i metodologiya kognitivnoy istorii [Theory and Methodology of Cognitive History] [in Russian]. Moskva [Moscow]: RGGU.

Panofsky, E. 1999. Smysl $i$ tolkovaniye izobrazitel'nogo iskusstva [Meaning of the Visual Arts] [in Russian]. Trans. from the English by V. V. Simonov. Sankt-Peterburg [Saint Petersburg]: Akademicheskiy proyekt. 
Pastoureau, M. 2019. Simvolicheskaya istoriya yevropeyskogo srednevekov'ya [Une histoire symbolique du Moyen Âge occidental] [in Russian]. Trans. from the French by Ye.S. Reshetnikova. Sankt-Peterburg [Saint Petersburg]: Aleksandriya.

Plugin, V. A. 1974. Mirovozzreniye Andreya Rubleva (Nekotoryye problemy) [Andrei Rublev's Worldview (Some Problems)]: Drevnerusskaya zhivopis' kak istoricheskiy istochnik [Old Russian Painting as a Historical Source] [in Russian]. Moskva [Moscow]: MGU.

Podobedova, O. I. 1965. Miniatyury russkikh istoricheskikh rukopisey ( $K$ istorii russkogo litsevogo letopisaniya) [Miniatures of Russian Historical Manuscripts (On the History of Russian Illustrated Annals)] [in Russian]. Moskva [Moscow]: Nauka.

Raushenbakh, B. R. 1975. Prostranstvennyye postroyeniya $v$ drevnerusskoy zhivopisi [Spatial Constructions in Ancient Russian Painting] [in Russian]. Moskva [Moscow]: Nauka.

Rumyantseva, M.F. 1999. "Metodologiya istorii A.S. Lappo-Danilevskogo i sovremennyye problemy gumanitarnogo znaniya [A.S. Lappo-Danilevsky Methodology of History and Contemporary Problems of Humanitarian Knowledge]" [in Russian]. Voprosy istorii [History Issues], no. 8: 138-146.

. 2017. "Istochnikovedeniye v strukture istoricheskogo znaniya [The Source Study in the Structure of Historical Knowledge]: neoklassichekaya model' nauki [The Neoclassical Model of Science]" [in Russian]. Uchenyye zapiski Petrozavodskogo gosudarstvennogo universiteta [Proceedings of Petrozavodsk State University] 166 (5): 44-51.

Shmidt, S.O. 1984. Rossiyskoye gosudarstvo v seredine XVI stoletiya. Tsarskiy arkhiv $i$ litsevyye letopisi vremeni Ivana Groznogo [The Russian State in the Middle of the 16 th Century. The Tsar's Archive and Facial Chronicles of the Time of Ivan the Terrible] [in Russian]. Moskva [Moscow]: Nauka.

- 1985. "O klassifikatsii istoricheskikh istochnikov [On the Classification of Historical Sources]" [in Russian]. Vspomogatel'nyye istoricheskiye distsipliny [Auxiliary Historical Disciplines] 16:3-24.

Shmidt, S. O., Ye. A. Belokon', and V. V. Morozov, eds. 2003. Litsevoy letopisnyy svod XVI veka [Illustrated Chronicle of the 16 th century]: Metodika opisaniya i izucheniya razroznennogo letopisnogo kompleksa [Methods for Describing and Studying the Scattered Chronicle Complex] [in Russian]. Moskva [Moscow]: RGGU.

Terent'yeva, L. A. 2010. "Izobrazitel'nyye istochniki [Figurative Sources]: vidovoye raznoobraziye [Species Diversity]" [in Russian]. In Mul'tikul'turnaya i mnogonatsional'naya Rossiya [Multicultural and Multinational Russia] : Materialy III mezhdunarodnoy mezhdistsiplinarnoy konferentsii. Chast' 1 [Materials of the 3 international interdisciplinary conference. Part 1], ed. by N. V. Boldovskaya and L. A. Terent'yeva, 470-484. Moskva [Moscow]: RUDN.

Tikhomirov, M. N. 1962. Istochnikovedeniye istorii SSSR. Vyp. 1 (S drevneyshikh vremen do kontsa XVIII veka) [Sources of the History of the USSR. Vol. 1 (From Ancient Times to the End of the 18th Century)] [in Russian]. Moskva [Moscow]: Izdatel'stvo sotsial'no-ekonomicheskoy literatury.

Uybo, A.S. 1983. "Informatsionnyy podkhod k tipologii istoricheskikh istochnikov [Information Approach to the Typology of Historical Sources]" [in Russian]. In Filosofskiye problemy istoricheskoy nauki [Philosophical Problems of Hstorical Science] : Trudy po filosofii [Works on Philosophy. Proceedings of Tartu University], ed. by E. Loone, 31-67. Tartu: Tartuskiy gosudarstvennyy universitet.

Uspenskiy, B. A. 1995. "Semiotika ikony [Semiotics of Icon]" [in Russian]. In Semiotika iskusstva [Semiotics of Art], 221-294. Moskva [Moscow]: Shkola "Yazyki russkoy kul'tury". 
Voronin, N. N. 1954. "Arkhitekturnyy pamyatnik kak istoricheskiy istochnik (zametki k postanovke voprosa) [Architectural Monument as a Historical Source (Notes on the Problem)]" [in Russian]. Sovet.skaya arkheologiya [Soviet Archeology], no. 19: 41-76.

Wrzosek, W. 2012. Kul'tura $i$ istoricheskaya istina [The Culture and the Historical Truth] [in Russian]. Trans. from the Polish by K. Yu. Yerusalimskiy. Moskva [Moscow]: Krug".

Yurganov, A. L. 2013. "Khudozhestvennyy yazyk drevney Rusi kak problema (na primere Litsevogo svoda Ivana Groznogo) [The Artistic Language of Ancient Russia as a Problem (on the Example of the Ivan the Terrible Illustrated Chronicle)]" [in Russian]. Rossiya XXI [Russia XXI], no. 3: 110-131. 